УДК 330.322(477)

(C) 2014

Чіп Л. О., кандидат економічних наук

Полтавська державна аграрна академія

\title{
ОСОБЛИВОСТІ ІНВЕСТИЦІЙНОГО КЛІМАТУ В УКРАЇНІ
}

\section{Рецензент - доктор економічних наук, професор Х. 3. Махмудов}

\begin{abstract}
Проаналізовано особливості, основні проблеми інвестиційного клімату в Украӥні, його виключну важливість для сприяння динаміки сочіальноекономічного розвитку та можливості модернізаціі на цій основі національної економіки. Розглянуто основні риси, тендениії інвестиційних процесів в Україні та напрями вдосконалення державної політики у сфері інвестування, а також заходи щзодо удосконалення правового поля у сфері інвестиційної діяльності. Акцентовано увагу на тому, щзо в Україні переважають негативні оцінки стосовно інвестииійного клімату, поскільки внутрішніх інвестииій недостатньо, щцоб забезпечити високу довгострокову динаміку, а темпи залучення прямих іноземних інвестицій як інвестииійного стимулятора - значно уповільнилися. Обтрунтовано необхідність, щзо на сучасному етапі розвитку економіки країни прямі іноземні інвестиції є невід'ємним компонентом ї̈ нормального функціонування. Висвітлено фундаментальну значущуість інвестииійної діяльності для чіткого окреслення національних інтересів з урахуванням впливів геополітичного середовища.
\end{abstract}

Ключові слова: інвестиційний клімат, стратегія сочіально-економічного розвитку, правова база, інвестииійний стимулятор, модернізація, структурна перебудова.

Постановка проблеми. Для будь-якої економіки нагальним $є$ питання досягнення макроекономічної стабільності, що неможливо без залучення інвестиційних ресурсів. Інвестування - це складний багатоступінчастий механізм, що дає змогу примножувати економічний потенціал країни. Останнім часом іноземні інвестори проводять обережну політику в країні у сфері інвестиційного співробітництва, що свідчить про необхідність зниження негативних факторів і створення максимально сприятливих умов для покращання інвестиційного клімату в Україні. Iнвестиційний клімат, як відомо, це сукупність об'єктивних і суб' єктивних умов, що сприяють або гальмують рух інвестиційних ресурсів для задоволення інвестиційних потреб економіки. $\mathrm{y}$ державі внутрішніх інвестиційних ресурсів недостатньо, щоб забезпечити розширене відтворення галузей економіки на базі науковотехнічного прогресу, нормального розвитку соціальної та виробничої інфраструктур.
На даному етапі залучення іноземних інвестицій вкрай загострюється через військові дії в Україні, що порушує поступальний рух економіки й нормальне ефективне функціонування в умовах інтеграційних процесів і геополітичних перетворень. Міжнародні інвестори мають чітко розуміти кінцеві цілі уряду України та окреслення пріоритетів для економіки, що потребує спеціального державного регулювання в цій сфері.

Світові надбання в даній галузі свідчать: розв'язання даної проблеми можливе за умов невідворотних демократичних перетворень i прозорості економічних процесів, а також чітких та послідовних дій у боротьбі з корупційними схемами, радикалізацією боротьби зі злочинністю й нехтуванням правовою базою.

Багаторічний вітчизняний і зарубіжний досвід із розкриття цієї проблеми має постійний, багатогранний i невичерпний характер, оскільки економічні реалії динамічно розвиваються, а отже, й аналіз висвітлення іiі також не є статичним, і наразі потребує постійної уваги.

Аналіз останніх досліджень і публікацій, у яких започатковано розв'язання проблеми. Наукових досліджень, що розкривають названу проблему, чимало. Недаремно їй надавалась і надається значна увага, так як у ринкових умовах економічного розвитку іноземні інвестиції $\epsilon$ однією 3 поширених форм міжнародного руху капіталів та його вкладання у виробництво тієї чи іншої продукції. Так, Я. Янишин [10] акцентує увагу на привабливості міжнародних інвестицій в Україну та їх впливові на економічний потенціал, В. Худавердієва [7] висвітлює стратегію залучення іноземних інвестицій в економіку крани на сучасному етапі розвитку, Н. Пітель [5] окреслює та аналізує проблему формування привабливого інвестиційного клімату в Україні, К. Фоміна [9] звертає увагу на особливості інвестування в країні, підкреслюючи роль вітчизняних і міжнародних інвестиційних фондів як одного зі шляхів залучення інвестицій. Переваги й недоліки із залучення іноземного капіталу та шляхів підвищення ефективності інвестицій в Україні розкриває В. Федоренко [8], а Н. Пашник [4] зазначає, що налагодження стабільного 


\section{EKOHOMIKA}

інвестиційного процесу $є$ справою особливого значення для України в нинішній час.

Однак потрібно враховувати, що на даному етапі революційних перетворень в Україні й чіткого вектора європейських пріоритетів особливості інвестиційних процесів набувають очевидної актуальності, що потребує подальшого аналізу й чіткого осмислення комплексних дій і послідовних підходів до створення привабливого економічного середовища із залучення іноземних інвестицій для економіки нашої країни, що надасть їй можливість для стабільного й незалежного економічного розвитку в реалізації нагальних проблем суспільно-економічного життя.

Мета дослідження: аналіз і подальший розвиток теоретико-прикладних засад із активізації інвестиційних процесів в Україні, висвітлення особливостей інвестиційного клімату та окреслення шляхів надходження іноземного капіталу, а також найсуттєвіших причин, що заважають цим процесам в умовах вкрай обмежених внутрішніх можливостей для фінансування економічних проектів за мінливості зовнішніх умов економічного співробітництва та розвитку країни.

Найважливішим завданням дослідження є систематизація актуальних даних у цій галузі та акцентування уваги на привабливості України як однієї з потенційно можливих провідних країн із залучення іноземних інвестицій.

Матеріали та методи дослідження. Для досягнення поставленої мети використані методи аналізу та синтезу щодо економічних процесів в Україні в ринкових умовах під час глобалізації та інтернаціоналізації економічних процесів, за яких інтенсифікація надходжень іноземних інвестицій дещо ускладнилася й потребує чіткого розуміння визначеності національних інтересів $\mathrm{i}$ місця економіки країни у світовому порядку на даному етапі іiі розвитку. Крім того у ході дослідження застосовувалися фундаментальні положення економіко-теоретичних надбань. Структурно-логічний аналіз - невід'ємна складова в розкритті даної проблеми. Використано також причинно-наслідковий аналіз. Поєднання нормативного і позитивного підходів застосовувалися нами щодо висвітлення теоретичних і практичних заходів вдосконалення інвестиційного клімату урядом України. Висновки базуються на основі методів комплексного й системного підходів.

Результати досліджень. Питання вдосконалення державної політики у сфері іноземного інвестування $є$ нагальним й актуальним. Поступальний розвиток економіки України та іiі соціально-економічних аспектів неможливі без наро- щування потенціалу галузей виробництва, що потребує істотних інвестиційних вкладень. Через об'єктивні обставини такі вкладання не завжди можуть бути забезпечені внутрішніми інвесторами, що, в свою чергу, потребує залучення іноземних інвестицій в економіку та заходів щодо активізації інвестиційних процесів в Україні. Відповідно до Закону України «Про інвестиційну діяльність» від 18.09.1991 року, «інвестиціями $є$ всі види майнових та інтелектуальних цінностей, що вкладаються в об'єкти підприємницької та інших видів діяльності, в результаті якої створюється прибуток (доход) або досягається соціальний ефект».

Наша країна потребує розширення та модернізації виробничого потенціалу. Вона може стати одним із провідних європейських реципієнтів інвестицій, так як володіє значним внутрішнім ринком, розгалуженим промисловим потенціалом, багатими та різноманітними природними ресурсами. Інвестиційна перевага України - ненасиченість і слабка конкуренція на ринку товарів і послуг. Україною успадкована потужна інфраструктура виводу добутої сировини, металів, хімічних добрив та зернових на світові ринки. Це нафто- і газопроводи, портове господарство, залізниця тощо. Країні необхідні оновлення діючих виробничих потужностей та виробничих фондів. На даний час в Україні поки що невисока порівняно 3 розвиненими країнами частка оплати праці у ВВП. Продуктивність праці в країні на підприємствах з іноземними інвестиціями вища, ніж на підприємствах без інвестицій, у середньому в 3,5 разу за рахунок інвестування в основні фонди з розрахунку на одного працівника, яке в іноземному секторі вище у 5-7 разів. Країна здатна освоювати додатковий капітал, володіючи людськими ресурсами (трудовими, управлінськими, адміністративними), які мають навички, необхідні для перетворення інвестиційних засобів у реальні інвестиції, а також ефективний платоспроможній попит на продукцію, вироблену в результаті інвестицій. Найбільш привабливими галузями для інвестування $€$ : оптова торгівля, харчова промисловість, видобуток нафти і газу, машинобудування, торгівля транспортними засобами, зв'язок [5].

Проблеми забезпечення сприятливого інвестиційного клімату в Україні залишаються питаннями стратегічної важливості, від реалізації яких залежать динаміка соціально-економічного розвитку й можливість модернізації на цій основі національної економіки. Оскільки в Конституції України наша держава визначена як «соціальна», що накладає на неї певні зобов'язання, 


\section{EKOHOMIKA}

вирішення яких неможливе без залучення інвестиційних ресурсів. Обсяги залучення іноземних інвестицій на душу населення в Україні у 100200 разів нижче, ніж у інших посткомуністичних європейських країнах.

Україна не змогла перебудуватися повністю із командно-адміністративної економіки в ринкову. Ці процеси проходять і зараз надто болюче. Висока заангажованість політичного простору, надмірна корупція спонукають до переосмислення сучасних реалій та розробки кардинальних заходів щодо стратегічних заходів покращання інвестиційного клімату. По суті, в наш час вперше формується по-справжньому пострадянське покоління, серед представників якого $є$ молоді економісти й політики, які повинні мислити сучасно і не упереджено, маючи можливість співставляти дані процеси в Україні зі світовим досвідом. Це дає надію на енергійні, вольові кроки щодо вирішення низки питань у плані поліпшення інвестиційної привабливості в Україні, а також розробки нових досліджень і теорій, оскільки класичні підходи іноді не є дієвими.

Водночас із перевагами існують і недоліки в залученні і функціонуванні іноземного капіталу.

Майже всі високорозвинуті країни світу, такі як Великобританія, Франція, Італія, Німеччина, США, створюючи сприятливе підгрунтя із залучення іноземних інвестицій, використовували їх для ефективного розвитку економіки. На сьогодні в Україні вже створено правове поле для здійснення інвестиційної діяльності. Зокрема, ця сфера регулюється Законами України: «Про ін- вестиційну діяльність», «Про режим іноземного інвестування», «Про захист іноземних інвестицій в Україні», «Про усунення дискримінації в оподаткуванні суб'єктів підприємницької діяльності, створених із використанням майна та коштів вітчизняного походження».

Обсяг надходжень іноземних інвестицій в Україні ще не відповідає нагальним потребам у них. Чистий приплив прямих іноземних інвестицій в Україну в 2013 році становив 2,86 млрд доларів, що вдвічі менше від показника 2012 року в (6,013 млрд доларів), про що йдеться в статистичних даних Держстату.

Станом на 1 січня 2014 року обсяг прямих іноземних інвестицій, внесених в економіку України 3 початку інвестування, становив 58,157 млрд доларів. У четвертому кварталі 2013 року (порівняно 3 третім кварталом) чистий приплив інвестицій становив 1,592 млрд доларів, а кількість країн-інвесторів знизилася на 2 країни - до 136 країн.

На кінець року основними інвесторами залишаються Кіпр (19,036 млрд доларів), Німеччина (6,292 млрд доларів), Нідерланди (5,562 млрд доларів), РФ (4,287 млрд доларів), Велика Британія (2,714 млрд доларів), Австрія (3,258 млрд доларів), Британські Віргінські острови $(2,494$ млрд доларів), Франція (1,826 млрд доларів), Швейцарія (1,325 млрд доларів), Італія (1,268 млрд доларів).

На ці країни припадає майже 83 \% від загального обсягу прямих інвестицій [3].

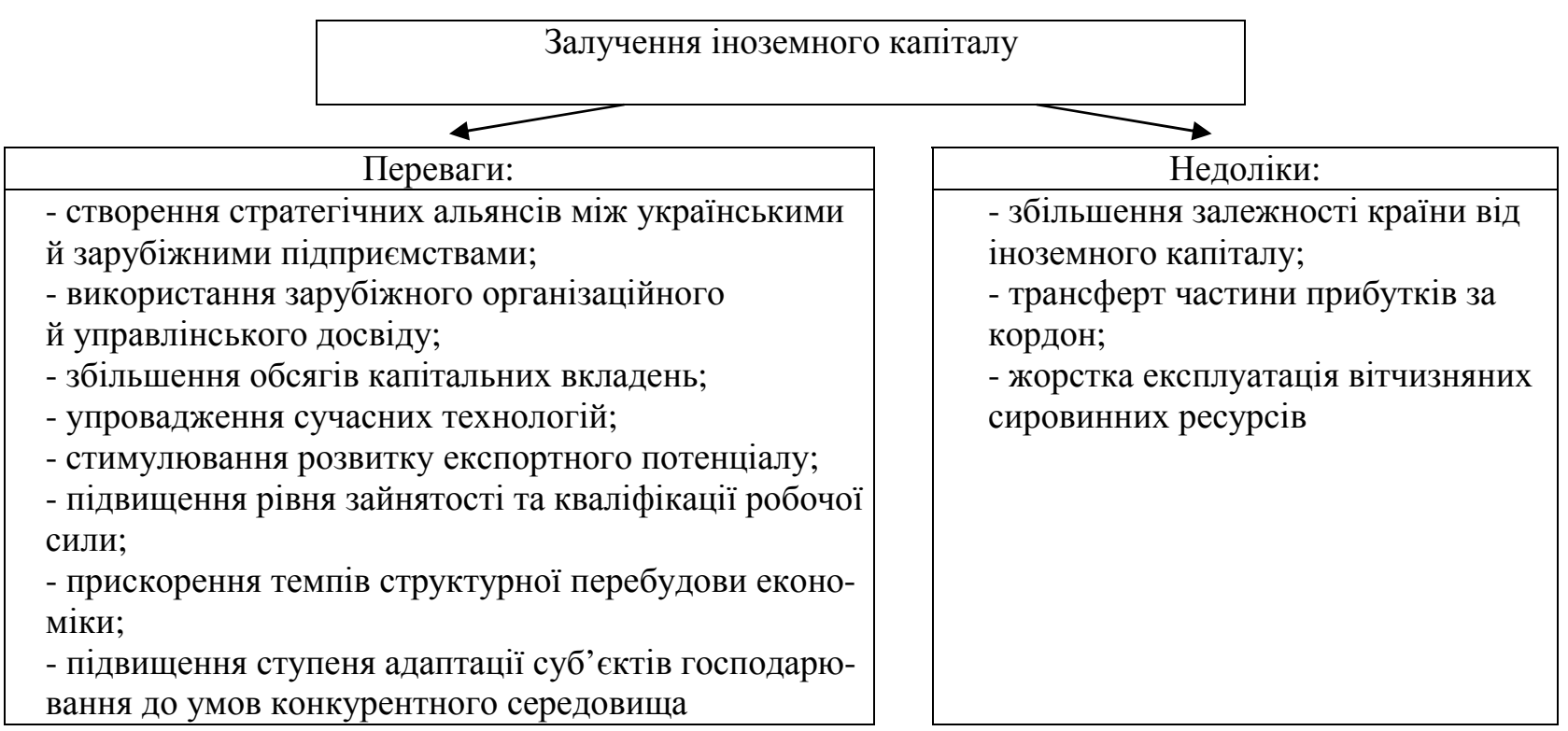

Рис. Переваги та недоліки залучення іноземного капіталу в економіку Украӥни [8] 


\section{ЕКОНОМІКА}

Інвестиційна політика Уряду України повинна бути націлена на створення умов, привабливих для інвестиційної діяльності, й потребувати публічної підтримки з боку інвесторів, а інвестори повинні займати активну позицію в дискусії 3 урядом у цій сфері задля однозначності перетворень та отримання очікуваних результатів.

Суттєвою перешкодою на шляху до залучення й ефективного використання іноземних інвестицій $є$ нерозвинена інфраструктура України. Я. Янишин зазначає, що $з$ метою удосконалення шляхів надходження зарубіжного капіталу слід створити мережу спеціальних установ як державних, так і не державних, які займатимуться підготовкою таких фахівців для України, готуватимуть відповідні інвестиційні проекти за міжнародними стандартами [10].

В Україні існує Рада інвесторів при Кабінеті Мiністрів України, але, як показують результати реальної економіки в країні, вона все-таки носить формальний характер і не виступає дієвим механізмом у діалозі підприємців з урядом.

Україна нині знаходиться на шляху всебічних економічних перетворень, а за таких умов налагодження стабільного інвестиційного процесу $\epsilon$ справою першорядного значення [4]. Країна, що залучає потужних інвесторів, має особливий авторитет і повагу на міжнародному рівні, а також більше шансів для реалізації очікувань щодо паритетних умов взаємодії серед світових організацій.

Забезпечувати залучення інвестицій можна різними способами: створенням спільних підприємств; додатковою емісією акцій; залученням коштів міжнародних і вітчизняних фінансових фондів; проведенням конкурсів, які б передбачали зобов' язання щодо розвитку підприємств [9]. Залучення інвестицій неможливо, однак, без макроекономічної стабілізації, на що розраховує інвестор. Зростання обсягів інвестицій для макроекономічної стабілізації країни необхідно забезпечити щорічними темпами зростання на рівні 10-12 \% ВВП. Для успішного залучення іноземних інвестицій необхідно формувати інвестиційну привабливість економічної системи країни. Запорукою інвестування повинні стати структурні реформи у приватному секторі, проте головне - це чітка правова база, що потребує однозначних трактувань, прозорості та передбачуваності поведінки всіх учасників ринку.

Однак притокові в інвестиційну сферу іноземного й приватного капіталу перешкоджають такі фактори як:

- нестабільність і невизначеність у законодавчому забезпеченні інвестиційної діяльності вза- галі й іноземних інвесторів зокрема;

- нестача комерційної та ринкової інформації;

- складність і непередбачуваність політичної ситуації;

- високий рівень корупції та тіньової економіки;

- нерозвиненість виробничої, соціальної та юридичної інфраструктур;

- неналежне застосування міжнародних стандартів бухгалтерського обліку та аудиту;

- недосконалість банківської системи;

- висока вартість і складність організації офісів;

- невисока купівельна спроможність більшості населення;

- недосконалість податкової системи;

- недосконалість механізмів іноземних інвестицій [2].

Неприйнятним також є рівень інвестицій у конкретні проекти. Простежується низький рівень інвестування у виробничу сферу та залучення портфельних інвестицій. Загальний обсяг прямих іноземних інвестицій, направлених в українську промисловість, становить $31 \%$ від їх загального обсягу, в установи фінансової та страхової діяльності - 26,4 \%, на підприємства торгівлі і ремонту автотранспорту - $13 \%$, у ринок нерухомості - 7,5\%, у наукову і технічну діяльність $-5,9 \%$. Заборгованість українських підприємств за кредитами і позиками, торговими кредитами та іншими зобов'язаннями перед прямими іноземними інвесторами на 1 січня 2014 року становила 10,155 млрд доларів [3].

Інвестиції відіграють двояку роль у макроекономіці. Оскільки вони є важливим і мінливим компонентом видатків, різке збільшення або зменшення інвестицій може здійснювати суттєвий вплив на сукупний попит, зміни якого, в свою чергу, впливають на випуск і зайнятість [6]. Існує прямий зв'язок щодо інвестицій і нарощування обсягів виробництва; зменшення дефіциту платіжного балансу; прискореного розвитку найважливіших галузей економіки; впровадження наукомістких технологій; освоєння родовищ корисних копалин, що дає змогу зменшувати рівень імпортованих ресурсів; підвищення попиту на товари; підвищення експорту вітчизняних виробників; збільшення бюджетних доходів, а відтак і поліпшення вирішення соціальних проблем, що сприяє зменшенню соціально-психологічної напруги в суспільстві.

Найбільш негативні аспекти, що гальмують інвестиції в економіку України, зосереджені в сферах діяльності: судової гілки влади; агропромисловому комплексі; банківській системі; земельних відносинах; фондовому ринку; податковій системі; в сфері технічного регулювання; корпоративному управ- 


\section{EKOHOMIKA}

лінні. У національній економіці існують перешкоди, що можуть обмежувати як самі інвестиції, так і ефективний попит на них.

На думку експертів Світового банку, підприємницький ризик інвестицій в Україні становить $80 \%$. Основними перешкодами для підвищення привабливості в очах як іноземних, так і внутрішніх інвесторів, є обтяжливі регуляторні процедури, зокрема:

- складність адміністрування податків;

- кількість і складність отримання дозволів;

- технічне регулювання (сертифікація та стандартизація);

- перевірки органів державного нагляду [1].

Головна особливість інвестиційного клімату в Україні - це те, що досить часто реальне економічне життя й обгрунтовані теоретичні методологічні та практичні розробки, дослідження провідних вчених, посадовців ідуть паралельними

\section{БІБЛІОГРАФІЯ}

1. Ведение бизнеса 2012 [Електронний ресурс] / Международный банк реконструкции и развития / Всемирный банк. - Режим доступу: http://russian.doingbusiness.org/data/exploreeconom ies/ukraine/

2. Лихолат C. М. Проблеми залучення іноземних інвестицій в економіці України / С. М. Лихолат, Н. І. Фляк // Науковий вісник НЛТУ. 2005. - №15. - С. 311-313.

3. Офіційний сайт державного комітету статистики України [Електронний ресурс]. - Режим доступу: http://www.ukrstat.gov.ua/

4. Пашник H. B. Проблеми та шляхи покращення інвестиційного клімату України/ Н. В. Пашник, А. О. Троїцька. - Режим доступу: http://intkonf.org/ pashnik-nv-trotska-ao-problemi-ta-shlyahipokraschennya-investitsivnogo-klimatu-ukraini/

5. Пітель Н. Я. Проблеми формування інвестиційного клімату України / Пітель Н. Я. [ Електронний ресурс]. - Режим доступу: http:// шляхами, не маючи точок зіткнення. $€$ велике сподівання, враховуючи бурхливі демократичні та економічні перетворення в Україні на даному етапі, що ситуація з часом докорінно зміниться.

Висновок. Україна володіє величезним аграрним та промисловим потенціалом, розвиток та нарощування потужностей якого в сучасних умовах неможливий без іноземних інвестицій. Державний сектор економіки також потребує значного залучення іноземного капіталу. Належний інвестиційний клімат у країні - це запорука тісного співробітництва 3 іноземними партнерами, які на даному етапі почувають себе невпевнено. Чіткі, однозначні та послідовні заходи уряду із забезпечення макроекономічної стабільності в країні та створення належної правової бази - запорука налагодження інвестиційного клімату.

www.nbuv.gov.ua/portal/Soc_Gum/Biznes/2010_3 /2010/03/100315. pdf

6. Самуельсон П. Экономика / Пол Е. Самуельсон, Вильям Д. Нордхаус. - 16-е изд. - М. : Издательський дом «Вильямс». - 2005. - 688 с.

7. Худавердієва B. А. Стратегія залучення іноземних інвестицій в економіку Ураїни / В. А. Худавердієва // Фінанси України. - 2010. - №6. - С. 62-71.

8. Федоренко В. Г. Шляхи підвищення ефективності інвестицій в Україні / В. Г. Федоренко // Наука. - №7. - 2003. - С.7-11.

9. Фоміна $K$. Особливості інвестування в Україну / К. Фоміна // Правовий тиждень. 2009. - №32. - C. 8-13.

10. Янишин Я. С. Привабливість міжнародних інвестицій в Україні / Я. С. Янишин, Ю. П. Кашуба // Економіка АПК. - 2012. - №7. - С. 63-69. 